\title{
MY DIARY
}

August 30th to November 5th, 1874 
THIS PAGE INTENTIONALLY LEFT BLANK 


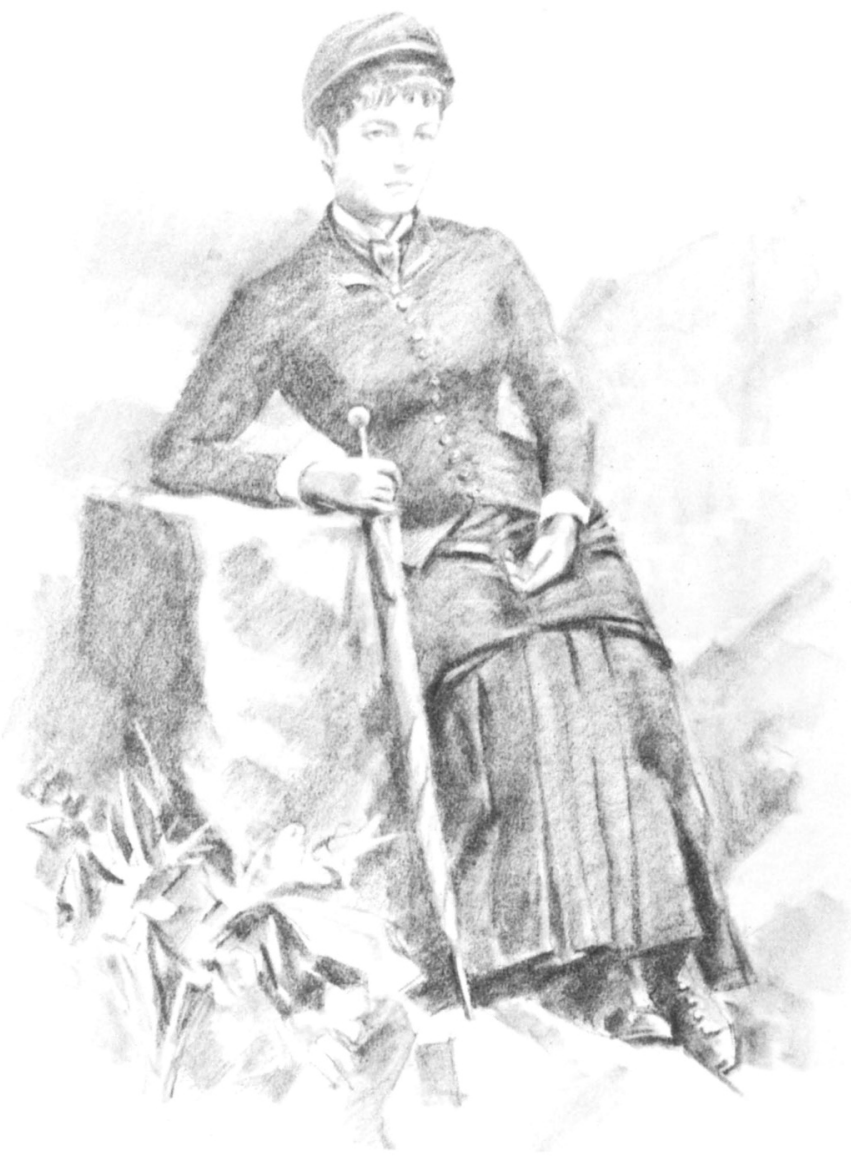

Cornelia Adair 
THIS PAGE INTENTIONALLY LEFT BLANK 


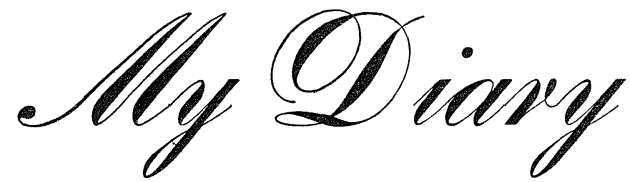

AUGUST 3OTH TO NOVEMBER 5TH, I 874

by Comelia Stair

Introduction by Montagu K. Brown

Illustrations by Malcolm Thurgood

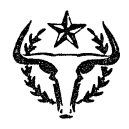

UNIVERSITY OF TEXAS PRESS, AUSTIN 
Copyright (@) 1965 by the University of Texas Press

\author{
All rights reserved \\ Printed in the United States of America
}

Requests for permission to reproduce material from this work should be sent to:

Permissions

University of Texas Press

P.O. Box 7819

Austin, TX 78713-7819

http://utpress.utexas.edu/index.php/rp-form

Library of Congress Catalog Number 65-11153

ISBN 978-1-4773-0058-9 (paperback)

ISBN 978-1-4773-0059-6 (library e-book)

ISBN 978-1-4773-0060-2 (individual e-book) 